ACTA THERIOLOGICA

Vol. 27, 34: $489-497,1982$

\title{
Polychloride and Carbamate Insecticide Contamination of Roe Deer Inhabiting Fields and Forests ${ }^{1}$
}

\author{
Andrzej KRYŃSKI, Jan KAEUZIŃSKI, Alicja DELONG, \\ Marek DUTKIEWICZ \& Lesław ŁABUDZKI
}

Kryński A., Kałuziński J., Delong A., Dutkiewicz M. \& Łabudzki L., 1982: Polychloride and carbamate insecticide contamination of roe deer inhabiting fields and forests. Acta theriol., 27, 34: 489-497 [With 2 Tables]

Chlorinated hydrocarbon residues were identified in the fatty tissue of roe deer from two different populations, inhabiting respectively forest and field, and an attempt made to define carbaryl level in samples taken from the brain, lungs and testes. One of the purposes of the study was to define insecticide residue in roe deer tissues depending on the amount of plant protection preparations introduced into the habitats in which these animals live. In samples of fatty tissue the combined concentration of DDD and metabolites, and of different metabolites, is many times higher in roe deer living in fields than in those in forests. No significant differences were found in the total concentration of DDT and metabolites and DDE in the fatty tissue of individuals of different sex, but originating from the same habitat. The significantly higher concentration of $\gamma-\mathrm{HCH}$ in the fatty tissue of fieldliving roe deer in comparison with forest-living roe deer is a characteristic phenomenon. The cumulation of $\gamma-\mathrm{HCH}$ in the organisms of field-living roe deer is the manifestation of the very general use of this pesticide for plant protection. Traces only of DMDT residue were found in only certain to the roe deer tissues examined from both field- and forest-living roe deer. Despite the general use of preparations containing carbaryl for plant protection no residue of this insecticide was found in roe deer tissue. All the concentrations of insecticide residues found in roe deer tissue are far below the levels laid down by FAO/WHO requirements for food substances.

[Warsaw Agric. Univ., Dept. Animal. Sci., 02-766 Warszawa, Nowoursynowska 166 ( $\mathrm{AK}, \mathrm{AD}, \mathrm{MD})$, Polish Hunting Association, Research Station, 62-055 Czempiń, Poland (JK), Poznań Agric. Acad., Inst. Forest Protection, Wojska Polskiego 71d, 60-625 Poznań, Poland (L€)]

\section{INTRODUCTION}

Insecticides, including chlorinated hydrocarbons and carbamates, have been used in modern agricultural and forest management for many years now. The wide use of these chemical compounds, primarily for plant protection in natural habitats, is also reflected in reproduction processes (Jaśkowski, 1976; Szukiel, 1969; Ware, 1975). Several studies on contamination by insecticides of tissues in wild animals have been

${ }^{1}$ Praca wykonana $\mathrm{w}$ ramach problemu MR-II/15 koordynowanego przez Instytut Ekologii PAN 
made (Jończyk et al., 1970; Ortwein, 1972; Dziliński, 1974, 1976; Delak et al., 1979; Frank et al., 1979; Osborn, 1980). There are no data in Polish literature on contamination of roe-deer tissues by insecticides from the group of chlorinated hydrocarbons and carbamates. In relation to studies on the trophic links of roe deer with a forest or field habitat it is also useful to determine possible differences in the contamination by insecticides of tissues in these animals. This question acquires a special significance when diametrically different amounts of insecticides are used in these habitats.

The present study, in addition to its purpose of fact-finding and recording the level of insecticides in roe deer tissues, depending on the amount of plant protection preparations used in the given habitat, may also facilitate differentiation between field-living and forest-living roe deer from the aspect of their food links with the place in which they live.

\section{MATERIAL AND METHODS}

The study material was obtained from the experimental area of the Polish Hunting Association Research Station at Czempin, and also from the forests of the "Zielonka" Hunting Experimental Centre of the Forest Protection Institute, Poznań Agricultural Academy.

The experimental area of the Station at Czempin occupies 15,000 ha, 14,000 ha of which is cultivated land, and is thus a typical agricultural habitat. The majority of the fields are under large-scale cultivation and form $70 \%$ of this area (Kałuziński \& Pielowski, 1976). Modern methods are applied in agricultural management there, with extensive use of machines and chemical preparations. A large roe deer population lives in this area, average density from 1977-79 being 12 individuals per 100 ha (Kałuziński, 1982). The Hunting Experimental Centre at Zielonka, 8,000 ha in extent, consists of a dense stretch of wooded land, with a small proportion of cultivated fields. Average density of roe deer in this area from 1977-79 was 15 individuals per 100 ha (Fruziński et al., 1982). The animals were obtained for the studies by shooting, and samples were taken from both does and bucks. The latter were obtained in both areas during the spring-summer period and does during the autumn-winter period. In the field area roe deer were obtained evenly over the whole experimental area, but in wooded land from its central part, situated at least $1000 \mathrm{~m}$ from cultivated fields.

Appropriate people were questioned in order to obtain data on the degree of use of chemical preparations in the field and forest habitats in 1978 (Table 1). Identification of chlorinated hydrocarbons and metabolites $\gamma$ - $\mathrm{HCH}-\gamma-1,2$, $3,4,5,6$, hexachlorocyclohexane; $\mathrm{p}, \mathrm{p}^{\prime} \mathrm{DDE}-2,2$, - di-(p-chlorophenylo) $-1,1$ - dichloroethylene, p, $\mathrm{p}^{\prime}$ DDD and TDE - 2,2 - di-(p-chlorophenyl); -1-1 dichloroethane; DDT - 2,2 - di-(p-chlorophenyl); - 1, 1, 1, - trichloroethane; DMDT 2,2-di-(p-methoxyphenyl); 1, 1, 1 - trichloroethane was carried out on fat samples from the fatty bursa enclosing the kidneys, taking fat samples from 22 forestliving and 49 field-living roe deer.

Endeavour was made to identify carbaryl (Union Carbide - Sevin) - (N-methylocarbamate; - 1-naphthyl) residue in 70 brain, 80 lung and 56 testis samples 
from field-living roe deer and 22 samples from the same organs, taken from forest-living deer.

Samples of tissue were taken approximately $1-2$ hours after the individual was shot. Until identification was carried out the tissues were kept frozen in polythylene packages at a temperature of $-20^{\circ} \mathrm{C}$. Fat samples were prepared for analysis and extraction of insecticides in accordance with the method given by Dzilinski et al., (1974). Identification of chlorinated hydrocarbons in roe deer fat was made by means of gas chromatography in a Pye-Unicam apparatus. Tissue samples, taken to discover carbaryl residue, were homogenized and extracted, then identification made by the thin-layer chromatography method, following the instructions given by Juszkiewicz et al. (1976) and Sokołowski et al. (1977).

Table 1

Chemical preparations used for plant protection at the Polish Hunting Association Research Station at Czempin in 1978.

\begin{tabular}{|c|c|c|c|c|c|}
\hline $\begin{array}{l}\text { Kind of } \\
\text { culture }\end{array}$ & $\begin{array}{l}\text { Chemicals } \\
\text { used }\end{array}$ & $\begin{array}{c}\text { Protected } \\
\text { area, ha }\end{array}$ & $\begin{array}{l}\text { Per } \\
1 \text { ha }\end{array}$ & $\begin{array}{c}\text { On the whole, } \\
\mathrm{kg} / \mathrm{ltr}\end{array}$ & $\begin{array}{c}\text { Recommen- } \\
\text { ded by } \\
\text { IPP }\end{array}$ \\
\hline \multirow{2}{*}{ Spring corn } & Chwastox & 1985 & 4 & 7940 & $3-5$ \\
\hline & Aminopielik & 111 & 4 & 333 & 3 \\
\hline \multirow[t]{4}{*}{ Rape } & Enolofos & 200 & 1 & 200 & $0.75-1$ \\
\hline & Mgławik & 600 & 7 & 4200 & $6-8$ \\
\hline & Gamametox & 200 & 7 & 1400 & to 20 \\
\hline & Gamakarbatox & 50 & 11 & 550 & to 20 \\
\hline \multirow[t]{5}{*}{ Sugar beet } & Venzar & 350 & 1 & 350 & $0.75-1.25$ \\
\hline & $\mathrm{Bi}-58$ & 560 & 0.6 & 336 & $0.6-0.8$ \\
\hline & Pyramin 4 & 150 & 4 & 600 & $4-5$ \\
\hline & Metation & 200 & 1 & 200 & 0.9 \\
\hline & Tinox 50 & 78 & 0.7 & 55 & $0.3-0.75$ \\
\hline \multirow[t]{2}{*}{ Maize } & Gesaprin 50 & 1800 & 3 & 5400 & $2-3$ \\
\hline & Simazin 80 WP & 678 & 3 & 2034 & 1.8 \\
\hline \multirow[t]{2}{*}{ Pea } & Aretit & 69 & 5 & 345 & $4-6$ \\
\hline & Afalon & 180 & 1.5 & 270 & $1.5-2$ \\
\hline \multirow[t]{3}{*}{ Potatoes 1} & Gamakarbatox & 250 & 2 & 500 & 1 \\
\hline & Afalon & 100 & 4 & 400 & 2 \\
\hline & Endofos 50 & 552 & 2 & 1044 & 0.75 \\
\hline
\end{tabular}

1 Preparation applied twice, ${ }^{2}$ IPP - Institute of Plant Protection

Statistical calculations were made by the variance analysis method in the twodirectional system (Oktaba, 1966). The Fischer-Snedecor $F$ test value for significance of differences was found for the following: 1 - between sexes 2 - between habitats, 3 - for the combined effect of sex and habitat. When $F$ test revealed significant differences in the effect examined, the smallest significant difference (NIR) was calculated in accordance with the equation $(t \times S r)$, where $t$ is the tabular value of the Student $t$ distribution with level of significance -0.01 , and $S r-$ average difference error.

\section{RESULTS}

Among the plant protection preparations used for cultivated plants on the Polish Hunting Association Research Station at Czempin in 1978 9 - Acta Theriologica 
were preparations containing $\gamma-\mathrm{HCH}, \mathrm{DMDT}$ and carbamates, these substances being included in such preparations at Mgławik, Gamametox and Gamakarbatox (Table 1). Preparations containing $\gamma-\mathrm{HCH}$, carbamates and DMDT were used chiedly in rape and potato fields. According to official information obtained from the agricultural service in the experimental part of the Station no preparations containing DDT were used in 1978 or for several years previous to that. The total dose of chemical preparations with which plants were treated over a combined area of 8083 ha was $26157 \mathrm{~kg}$, but this amount contains only $2450 \mathrm{~kg}$ of insecticides subject to cumulation in the animals' organisms (Table 1).

Table 2

Average concentration of polychloride insecticides in $\mathrm{ppm} / \mathrm{mg} / \mathrm{kg}$ in the fatty tissue of roe deer from field and forest habitats.

\begin{tabular}{|c|c|c|c|c|c|c|c|c|}
\hline \multirow{2}{*}{ Items } & \multicolumn{2}{|c|}{$\gamma-\mathrm{HCH}$} & \multicolumn{2}{|c|}{ p.p' - DDE } & \multirow{2}{*}{$\begin{array}{l}\text { p.p' } \\
\text { Forest }\end{array}$} & \multirow{2}{*}{$\begin{array}{l}\text { DDD } \\
\text { Field }\end{array}$} & \multicolumn{2}{|c|}{ DDT+metabolites } \\
\hline & Forest & Field & Forest & Field & & & Forest & Field \\
\hline Males & 0.071 & 0.104 & 0.046 & 0.352 & 0.033 & 0.135 & 0.056 & 0.603 \\
\hline $\mathrm{n}$ & 14 & 20 & 14 & 20 & 14 & 18 & 14 & 20 \\
\hline Females & 0.096 & 0.505 & 0.060 & 0.363 & 0.028 & 0.037 & 0.069 & 0.598 \\
\hline $\mathrm{n}$ & 8 & 27 & 7 & 29 & & 29 & & 29 \\
\hline $\mathrm{NIR}^{1}$ & \multicolumn{2}{|c|}{0.100} & \multicolumn{2}{|c|}{0.070} & \multicolumn{2}{|c|}{0.030} & \multicolumn{2}{|c|}{0.086} \\
\hline NIR $^{2}$ & \multicolumn{2}{|c|}{0.100} & \multirow{2}{*}{\multicolumn{2}{|c|}{$\begin{array}{l}0.070 \\
0.090\end{array}$}} & \multicolumn{2}{|c|}{0.030} & \multicolumn{2}{|c|}{0.086} \\
\hline $\mathrm{NIR}^{3}$ & \multicolumn{2}{|c|}{0.160} & & & \multicolumn{2}{|c|}{0.050} & \multicolumn{2}{|c|}{0.120} \\
\hline
\end{tabular}

Forest - forest-living roe deer, Field - field-living roe deer, $\mathrm{n}$ - number of individuals, NIR - smallest proved difference $(t \times S r)$, NIR ${ }^{1}$ for sex, $N^{2}{ }^{2}$ for territory, NIR ${ }^{3}$ for cooperation of sex and territory.

Chemical preparations for plant protection were used only to a very slight degree in the wooded area of the "Zielonka" Experimental Centre. Small amounts of insecticides and herbicides were used in a small number of enclosed experimental plots several ares in extent, to which roe deer had no access.

Data obtained on the average concentration of chlorinated hydrocarbons in roe deer fatty tissue showed that both combined DDD and metabolites concentration, and that of different metabolites, is many times greater in field-living roe deer, whether bucks or does, than in forest-living roe deer. No significant differences were found in the total concentrations od DDT and metabolites, or of DDE, in the fatty tissue of individuals of different sex but originating from the same habitats. It was only in the case of DDD that significantly higher concentration was found in field-living roebucks as compared with does (Table 2). It is characteristics fact that the percentage of the concentration of DDE and DDD metabolites in the total pool of combined DDT and metabolites is fairly considerable, in the tissues of both forest-living and field-living roe deer. 
$\gamma$-HCH concentration found in the fat of the field-living does is significantly higher when compared with relevant data for individuals of the same sex from the forest population. When the concentration of this insecticide in the field population is considered, it is evident that the levels of $\gamma-\mathrm{HCH}$ are significantly higher in does than in bucks. In the groups of males the level of $\gamma-\mathrm{HCH}$ concentration was found to be higher in bucks from fields than from wooded land, but the difference proved to be statistically insignificant (Table 2).

Studies were also made in order to discover DMDT contamination in the tissues of roe deer from fields and wooded land. A joint total of twenty two samples from eight does and fourteen bucks were taken from the forest population. No traces of this insecticide were found in the fatty tissue of females, whereas in twelve samples of male tissues the average DMDT concentration was $0.045 \mathrm{ppm}$, with a range from $0.011-0.120 \mathrm{ppm}$. DMDT contamination of fatty tissue in roe deer from fields was as follows. In not a single case out of twenty samples taken from bucks were any traces of this insecticide found. Among twenty nine samples of fatty tissue taken from does DMDT was found in eighteen cases, while average concentration was $0.018 \mathrm{ppm}$, with a range from $0.006-0.052 \mathrm{ppm}$.

The relatively low DMDT concentration found for field-living and forest-living roe deer made it impossible to carry out statistical analysis.

Endeavour was made to identify carbaryl content in samples taken from the lungs, brain and tests in roe deer from both the field and forest populations. No perceptible carbaryl residue was found in any of above organs from individuals from either the forest and field population.

\section{DISCUSSION}

The results obtained point to a very much higher level of chlorinated hydrocarbons in the fatty tissue of roe deer living in a field habitat as compared with a forest habitat. Although DDT has ceased to be used for several years in agrotechnical operations, DDT and metabolite residues were discovered in roe deer fatty tissue. In view of the lack of other Polish studies on DDT level in roe deer fatty tissue it is difficult to estimate variation dynamics in this concentration in time. From 1973-75 similar studies were carried out in Croatia, but the level of DDT concentration found in roe deer fatty tissue was from 0.009 $0.292 \mathrm{ppm}$ (Delak et al., 1979), and was thus similar to the result obtained in the present study. Similar DDT concentration has been found in other herbivorous animals. In the fatty tissue of horses average 
concentration of total DDT and metabolites is $0.573 \mathrm{ppm}$ (Kosmala, 1972). In the European hare, depending on age and sex, the total amount of DDT varied from $0.34-1.23 \mathrm{ppm}$ (Dziliński et al., 1974; 1976). The total concentrations presented above for roe deer and other herbivorous animals are, however, far lower than is envisaged by foodstuff standards established by FAO/WHO recommendations $(7 \mathrm{mg} / \mathrm{kg}$ - Dzilinski et al., 1974 ) and $1.25 \mathrm{mg}$ DDT/kg for a food product with over $8 \%$ fat content - Nikonorow, 1980).

Roe deer living in fields, unlike those living in forests, are characterized by a significantly higher $\gamma-\mathrm{HCH}$ concentration in fatty tissue. $\mathrm{Cu}$ mulation of this compound in the field-living roe deer's organism is the manifestation of the greater use of this pesticide in the habitat of cultivated fields. In recent years the use of DDT has been abandoned in favour of $\gamma-\mathrm{HCH}$. According to earlier unpublished data obtained at the Research Station at Czempin (for the period 1972-73) $\gamma-\mathrm{HCH}$ concentration in perirenal fat in roe deer varied over a range from $0.010-0.179$, but in 1978 in individuals from the same population the average figure for bucks was $0.104 \mathrm{ppm}$ and for does as much as $0.505 \mathrm{ppm}$. These data give a good picture of the process in increasingly wide use of $\gamma-\mathrm{HCH}$ for plant protection in field areas. A similar level of $\gamma-\mathrm{HCH}$ concentration of approx. $0.46 \mathrm{ppm}$ in the fatty tissue of partridges was found by Jończyk et al. (1970). A far lower average concentration of $0.0186 \mathrm{ppm}$ was found by Dziliński et al. (1976) in the hare.

None of the $\gamma-\mathrm{HCH}$ residues presented above exceed the practical limit, which for meat for food purposes is $1.00 \mathrm{mg} / \mathrm{kg}$, calculated for fat (Nikonorow, 1980).

The problem of significantly higher $\gamma-\mathrm{HCH}$ concentration in the fatty tissues of does than in bucks among roe deer living in fields is surprising. The cause of this difference may lie in the fact that the males and females from which samples were obtained were shot at different periods, since bucks were obtained during the spring-summer months, and does during the autumn-winter months. Bucks thus consume insecticides from a contaminated habitat for a shorter time, since these preparations are particularly intensively used in spring and summer. This same phenomenon has been recorded for wooded land, but the lower level of contamination of this habitat directly results in differences in the level of $\gamma-\mathrm{HCH}$ residue found in males and females not being statistically significant.

Traces of DMDT were found only in some of the samples of roe deer fatty tissue examined. Similar observations on this subject have been made by other authors in examining the fat of game animals (Dziliński 
et al., 1974, 1976; Frank et al., 1979). This is a known phenomenon, caused by the lower degree of accumulation of this insecticide in comparison with, say, DDT (Reynolds et al., 1976).

Despite the general use of preparation containing carbaryl, in particular for potato protection in field areas, no residues of these preparations were found in the fatty tissue of the roe deer. This fact may be explained by the relatively rapid decomposition of carbamates in animal organisms, followed by their complete excretion. Results similar to the above were obtained by Blas et al., 1976; Juszkiewicz et al., 1976; White-Stevenson, 1977. In this connection it may be assumed that carbaryl derivatives used for plant protection as pesticides are not of any great significance in contamination of roe deer tissues.

In the light of the results obtained it may be said that roe deer obtained from an agricultural habitat are continuously tied to the place in which they live for a considerable time, and the degree of contamination of their tissues is a reflection of the fact that they feed on field plants treated with various plant protection preparations. This is confirmed by Kałuziński's studies (1982) on the basis of which it is known that $66 \%$ of the food of field-living roe deer consists of cultivated plants. Forest-living roe deer, on the other hand, on the principle of the same relations as above, due to the far lower level of insecticide residues, have close trophic contacts with the habitat in which they were shot.

\section{REFERENCES}

1. Blase B. W. \& Loomes T. A., 1976: The uptake and metabolism of carbaryl by isolated perfused rabbit lung. Toxicol. Appl. Pharmacol., 37: 481-490.

2. Delak M., Radakovič M. \& Žukovič J., 1979: Ostataci klorivanich ugljikovodika pesticidnich svojstva u srnama i jelenima na podruciju SR Hrvatske. Veterinarski Archiv. 49: 113-119.

3. Dziliński E. \& Ortwein L., 1974: Poziom pestycydów polichlorowych $w$ tłuszczu zająca szaraka (Lepus europaeus Pallas) z terenu Wielkopolski. Med. wet., 30: $494-496$.

4. Dziliński E. \& Chlewski A., 1976: Estimated residues of polychloric insecticides in the fatty tissues of the European hare. [In: "Ecology and management of European hare populations", Eds. Pielowski Z. \& Pucek Z.]. Państw. Wyd. Roln. i Leśne: 213-217. Warszawa.

5. Frank R., Holdrinet M. \& Suda P., 1979: Organochlorine and mercury residues in wild mammals in southern Ontario, Canada 1973-1974. Bull, envir. Contam. \& Toxicol., 22: 500-507.

6. Fruziński B., Łabudzki L. \& Wlazełko M., 1983: Habitat, density and spatial structure of roe deer population in forest. Acta theriol., 28.

7. Jaśkowski L., 1976: Wpływ pestycydów na płodność zwierząt. Med. wet., 32: $323-325$. 
8. Jończyk H., Dmoch I. \& Bojanowska A., 1970: Zawartość węglowodorów chlorowanych $\mathrm{w}$ tkance tłuszczowej i mózgu kuropatw (Perdix perdix L.). Roczn $\mathrm{PZH}, 21: 409-415$.

9. Juszkiewicz T., Żuk M., Cybulski W. \& Minta M., 1976: Pozostałości karbarylu i 1-naftolu w tkankach i jajach kur skażonych doświadczalnie. Med. wet., 32: $272-275$.

10. Kałuziński J. \& Pielowski Z., 1976: The effect of technical agricultural operations on the hare population. [In: "Ecology and management of European hare populations", Eds. Pielowski Z. \& Pucek Z.]. Państw. Wyd. Roln. i Leśne: 205-211. Warszawa.

11. Kałuziński J., 1982: Dynamics and structure of a field roe deer population. Acta theriol., 27: 385-408.

12. Kosmala K., 1973: Pozostałości pestycydów polichlorowych w tkance tluszczowej koni. Med. wet., 28: $684-685$.

13. Nikonorow M., 1980: Zanieczyszczenia chemiczne i biologiczne żywności. Wyd. Nauk. Techn.: 195-200. Warszawa.

14. Oktaba W., 1966: Elementy statystyki matematycznej i metodyka doświadczalnictwa. Państw. Wyd. Nauk.: 234-240. Warszawa.

15. Ortwein L., 1972: Badania nad skażeniami zająca szaraka insektycydami z grupy chlorowanych węglowodorów. Prace nauk. IOR, 14: 83-144.

16. Osborn D., 1980: Pesticides and British wildlife - brief review of some recent work at Monks Wood. J. Royal Soc. Med., 73: 127-130.

17. Reynolds P. J., Lindahl I. L., Cecil H. C. \& Bitman J., 1976: A comparison of DDT and metoxychlor accumulation and depletion in sheep. Bull. environ. Contam. \& Toxicol., 16: 240-247.

18. Sokołowski M. \& Juszkiewicz G., 1977: Diagnostyka zatruć pszczół preparatami ochrony roślin z grupy karbaminianów. Med. wet., 33: 220-221.

19. Szukiel E., 1969: Wpływ środków ochrony roślin na świat zwierząt. Łowiec pol, 15: (1354) 16.

20. Ware G. W., 1975: Effects of DDT on reproduction in higher animals. Residue Reviews, 59: 120-140.

21. White-Stevenson R., 1977: Pestycydy a środowisko. Państw. Wyd. Roln. i Leśne: 120-121. Warszawa.

Accepted, May 17, 1982.

KRYŃSKI A., KA£UZIŃSKI J., DELONG A., DUTKIEWICZ M. i ŁABUDZKI L.

OCEUA SKAŻEÑ SARN ZAMIESZKUJĄCYCH TERENY LESNE I POLNE INSEKTYCYDAMI Z GRUPY CHLOROWANYCH WEGLOWODOROW I KARBAMINIANOW

Streszczenie

Powszechne stosowanie chlorowanych węglowodorów i karbaminianów w ochronie roślin znajduje swoje odzwierciedlenie w stężeniu pozostałości tych związków chemicznych w tkankach zwierząt wolnożyjących. Celem niniejszej pracy było poznanie poziomu insektycydów w tkankach sarn, pozyskanych z populacji leśnej i pol- 
nej. Srodowisko polne różni się między innymi od leśnego ilościami stosowanych środków ochrony roślin, co znalazło swoje odzwierciedlenie w stężeniu insektycydów w tkankach sarn. Uzyskane wyniki stężenia sumy DDD i metabolitów są wielokrotnie wyższe u sarn polnych niż u leśnych. Nie stwierdzono istotnych różnic w stężeniu sumy DDT i metabolitów oraz DDE w tkance tluszczowej samców i samic pochodzących $z$ tych samych populacji. Kumulacja $\gamma-\mathrm{HCH}$ w organizmach sarn polnych jest wykładnikiem coraz powszechniejszego stosowania tego pestycydu $w$ ochronie roślin oraz czasokresu stykania się $\mathrm{z}$ tym preparatem. DMDT stwierdzono tylko u niektórych osobników z populacji polnej i leśnej i to tylko w śladowych ilościach.

Pomimo powszechnego użycia preparatów zawierających karbaryl w ochronie roślin nie stwierdzono pozostałości tego insektycydu w tkankach sarn polnych i leśnych. Fakt ten tłumaczyć można szybkim całkowitym wydalaniem tych związków przez organizmy sarn. Wszystkie stwierdzone w niniejszej pracy stężenia pozostałości insektycydów $w$ tkankach sarn polnych i leśnych znajdują się znacznie poniżej poziomów przyjętych ustaleniami FAO/WHO dla środków spożywczych.

W świetle uzyskanych danych stwierdzić można, że sarny pozyskane na polach lub w lesie od dłuższego czasu miały ścisły, trwały kontakt ze środowiskiem, w którym zostały pozyskane. 